\title{
Study of Uptake Mechanisms of Halloysite Nanotubes in Different Cell Lines
}

\author{
Giuseppa Biddeci ${ }^{1,2}$ \\ Gaetano Spinelli ${ }^{1}$ \\ Marina Massaro ${ }^{2}$ \\ Serena Riela ${ }^{2}$ \\ Paola Bonaccorsi ${ }^{3}$ \\ Anna Barattucci ${ }^{3}$ \\ Francesco Di Blasi ${ }^{1}$
}

'Institute for Innovation and Biomedical Research (IRIB), CNR, Palermo, 90I46, Italy; ${ }^{2}$ Department of Biological, Chemical and Pharmaceutical Sciences and Technologies (STEBICEF), Sect. Chemistry, University of Palermo, Palermo, 90I28, Italy; ${ }^{3}$ Department of Chemical, Biological, Pharmaceutical and Environmental Sciences, University of Messina, Messina, 98I58, Italy
Correspondence: Francesco Di Blasi Institute for Innovation and Biomedical Research (IRIB), CNR, Via Ugo La Malfa I53, Palermo, 90|46, Italy

Tel +390916809514

Email francesco.diblasi@irib.cnr.it
Purpose: Halloysite nanotubes (HNTs) are a natural aluminosilicate clay with a chemical formula of $\mathrm{Al}_{2} \mathrm{Si}_{2} \mathrm{O}_{5}(\mathrm{OH})_{4} \times \mathrm{nH}_{2} \mathrm{O}$ and a hollow tubular structure. Due to their peculiar structure, HNTs can play an important role as a drug carrier system. Currently, the mechanism by which HNTs are internalized into living cells, and what is the transport pathway, is still unclear. Therefore, this study aimed at establishing the in vitro mechanism by which halloysite nanotubes could be internalized, using phagocytic and non-phagocytic cell lines as models.

Methods: The HNT/CURBO hybrid system, where a fluorescent probe (CURBO) is confined in the HNT lumen, has been used as a model to study the transport pathway mechanisms of HNTs. The cytocompatibility of HNT/CURBO on cell lines model was investigated by MTS assay. In order to identify the internalization pathway involved in the cellular uptake, we performed various endocytosis-inhibiting studies, and we used fluorescence microscopy to verify the nanomaterial internalization by cells. We evaluated the haemolytic effect of HNT/CURBO placed in contact with human red blood cells (HRBCs), by reading the absorbance value of the supernatant at $570 \mathrm{~nm}$.

Results: The HNT/CURBO is highly biocompatible and does not have an appreciable haemolytic effect. The results of the inhibition tests have shown that the internalization process of nanotubes occurs in an energy-dependent manner in both the investigated cell lines, although they have different characteristics. In particular, in non-phagocytic cells, clathrin-dependent and independent endocytosis are involved. In phagocytic cells, in addition to phagocytosis and clathrin-dependent endocytosis, microtubules also participate in the halloysite cellular trafficking. Upon internalization by cells, HNT/CURBO is localized in the cytoplasmic area, particularly in the perinuclear region.

Conclusion: Understanding the cellular transport pathways of HNTs can help in the rational design of novel drug delivery systems and can be of great value for their applications in biotechnology.

Keywords: halloysite nanotubes, endocytic pathway, cellular internalization, biocompatibility, hemocompatibility

\section{Introduction}

Drug carrier systems based on nanomaterials have attracted a lot of attention over the past few years thanks to their great potential and the biocompatibility of biomaterials has gained great significance. In the study of biological responses to materials, evaluation of cytotoxicity is the preliminary screening test used for almost all materials. ${ }^{1}$ Halloysite is a two-layered aluminosilicate, with chemical composition similar to kaolinite, which has the following chemical formula $\left(\mathrm{Al}_{2} \mathrm{Si}_{2} \mathrm{O}_{5}(\mathrm{OH})_{4} \cdot n \mathrm{H}_{2} \mathrm{O}\right)^{2,3}$ and

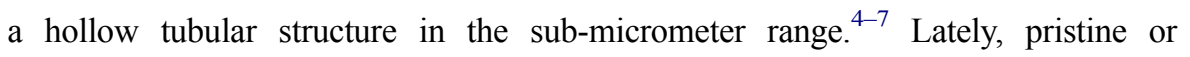


functionalized HNTs have obtained increasingly attention as drug delivery systems into cells. They have been reported to have a good biocompatibility and safety profile following the cellular internalization. ${ }^{8-12}$ Due to their properties, HNTs could be used for the encapsulation of drugs, biologically active molecules ${ }^{3,13-19}$ and as potential non-viral vector for oral gene therapy. ${ }^{12,20}$ Moreover, thanks to their large specific surface area, high biocompatibility and nanotubular structure, HNTs are used as support materials and for the loading and controlled release study of various substances. ${ }^{21-25}$

For example, understanding which pathways could be involved in the cellular uptake of this non-viral vector may help designing more effective gene carriers. Generally, nanoparticles internalization by cells is mainly dependent on size, surface charge and functionalization. ${ }^{26}$ Although it is known that halloysite nanotubes can pass through the plasma membrane and enter cells, the exact mechanism by which they are internalized in the cells is not yet well established. ${ }^{27}$ For further development of HNTs as a drug carrier system, it is essential to further investigate this topic, in order to better understand the specific mechanism by which they are internalized in living cells. Therefore, our aim in this work is to study the mechanisms involved in the cellular uptake of halloysite nanotubes by various endocytosis-inhibiting studies and fluorescence microscopy. To this end, since nanotubes do not possess photo-luminescent properties, the hybrid system HNT/CURBO has been used, in which the fluorescent probe CURBO is supramolecularly loaded into the HNT lumen (Figure 1). ${ }^{28}$

The peculiarity of this hybrid system is that the fluorescent probe has a great affinity for the lumen, so is very similar to pristine halloysite nanotubes because the external surface does not have any type of functionalization. This allowed us to study the interaction with the plasma membrane, without any influence that could be given by the addition of functional groups on the external surface. The focus of our study was on two cell types that have distinct barrier functions. In particular, different endocytic uptake mechanisms were investigated using a mouse macrophage cell line (Raw 264.7) that is widely used as a model for primary macrophages, ${ }^{29}$ and a human epithelial cell line (HeLa) as models. The different characteristics of the two cell lines studied could involve distinct internalization pathways. The cell membrane is a thin semi-permeable membrane that protects all the intracellular components from the surrounding environment. The cell membrane is therefore involved in maintaining cell homeostasis, serves as structural support for the cell and helps maintaining its shape, maintaining ion concentration gradients and controlling the entry and exit of nutrients and small molecules. ${ }^{30-33}$ Entry through the cell membrane can occur by passive diffusion or through other mechanisms, for example channel, receptor, or transporter. ${ }^{34-36}$ Currently, several mechanisms have been identified by which nanoparticles enter inside the cells. Various endocytic processes enclose nanoparticles in membrane vesicles in an energy-dependent manner. Mainly, endocytosis can be classified into two categories: phagocytosis and pinocytosis. Phagocytosis is a relevant process that occurs in specialized cells as mononuclear phagocytes and neutrophils. Particle internalization consists mainly in the interaction, recognition and ingestion by a vesicle derived by plasmatic membrane called phagosome. ${ }^{37-39}$ Pinocytosis can be divided into micropinocytosis, clathrin-dependent (CDE) and clathrin-independent endocytosis (CIE). ${ }^{40,41} \mathrm{In}$ order to identify the internalization pathway of the HNT/ CURBO, we used different drugs to selectively inhibit the various endocytic processes: Sodium azide $\left(\mathrm{NaN}_{3}\right)$; Chlorpromazine hydrochloride; Cytochalasin D and Nocodazole. Sodium azide, is commonly used to deplete cellular ATP levels and to generally inhibit endocytosis or energy-dependent process. ${ }^{42-45}$ Chlorpromazine hydrochloride is used to inhibit $\mathrm{CDE}$, it can inhibit clathrin-coated pit formation by a reversible translocation of clathrin and its adapter proteins from the plasma membrane to intracellular vesicles. ${ }^{41,46-48}$ Cytochalasin-D-induced depolymerization of f-actin, ${ }^{49}$ can be used to inhibit phagocytosis, and

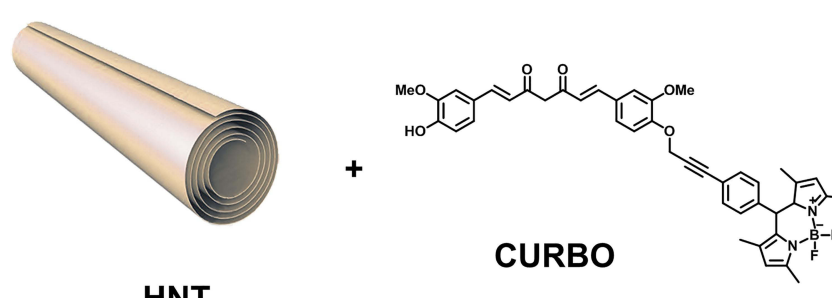

HNT

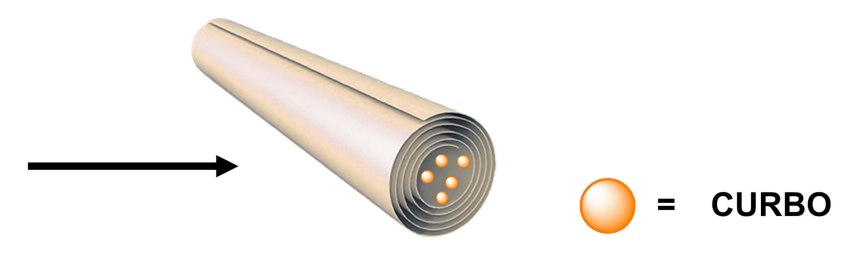

HNT/CURBO

Figure I Hybrid system HNT/CURBO obtained by supramolecular inclusion with the fluorescent probe CURBO in the lumen of the tubes. 
clathrin/caveolin-independent endocytosis. ${ }^{50-54}$ Nocodazole is a pharmacological inhibitor for microtubule polymerization, which is responsible for a variety of cell movements, including intracellular transport. ${ }^{55}$ Before proceeding with internalization studies, as these drugs can induce adverse effects, the cytotoxicity was tested by MTS assay in both cell lines used as model, examining cell respiration by mitochondrial dehydrogenase activity. The use of nanomaterials for applications in the biomedical field requires that these induce, upon contact with red blood cells (RBCs), a percentage of hemolysis that is less than or equal to $5 \%$. Blood compatibility is another important prerequisite for biomaterials, despite the cytocompatibility of HNTs has been widely considered, little is known about halloysite and hemocompatibility. Herein, we performed a hemocompatibility test, to study the red blood cells stability when in contact with the HNT/CURBO. The hemolysis ratio of HNTs, CURBO and HNT/CURBO was tested in vitro on human red blood cells (HRBCs).

\section{Materials and Methods Materials}

Cytochalasin D, Chlorpromazine H, Sodium azide and Nocodazole were obtained from Sigma-Aldrich. Fetal bovine serum (FBS), Roswell Park Memorial Institute (RPMI) 1640 medium, trypsin and penicillin-streptomycin were purchased by Gibco Life Technologies. Halloysite was purchased from Sigma-Aldrich by Merck and used without further purification. Halloysite has an average tube diameter of $50 \mathrm{~nm}$ and inner lumen diameter of $15 \mathrm{~nm}$. Typical specific surface area is $65 \mathrm{~m}^{2} \mathrm{~g}^{-1}$; pore volume of $\sim 1.25 \mathrm{~cm}^{3} \mathrm{~g}^{-1}$; refractive index 1.54 and specific gravity $2.53 \mathrm{~g} \mathrm{~cm}^{-3}$.

HNT/CURBO was synthetized as reported elsewhere. ${ }^{28}$

\section{Cell Culture}

Human cervical cancer cells (HeLa cells) were purchased by ATCC (American Type Culture Collection) and cultured in Roswell Park Memorial Institute (RPMI) 1640 medium supplemented with 5\% Fetal Bovine Serum (FBS) and $2 \mathrm{mM}$ L-glutamine, 100 units per $\mathrm{mL}$ penicillin and $100 \mathrm{mg} / \mathrm{mL}$ streptomycin and incubated in a humidified atmosphere at $37{ }^{\circ} \mathrm{C}$ in $5 \% \mathrm{CO}_{2}$. Murine macrophage cells (Raw 264.7 cells) were purchased by ATCC and were maintained in RPMI medium supplemented with $10 \%$ FBS and $2 \mathrm{mM}$ L-glutamine, 100 units per $\mathrm{mL}$ penicillin and $100 \mathrm{mg} / \mathrm{mL}$ streptomycin and incubated in a $5 \% \mathrm{CO}_{2}$ humidified atmosphere at $37^{\circ} \mathrm{C}$ in $\mathrm{CO}_{2}$ incubator.

\section{Biocompatibility of HNT/CURBO on HeLa and Raw 264.7 Cells}

HeLa and Raw 264.7 cells were seeded at a density of $1 \times 10^{4}$ cells per well in a flat-bottom 96-well plate and incubated for $24 \mathrm{~h}$ at $37^{\circ} \mathrm{C}$ in $5 \% \mathrm{CO}_{2}$. Afterwards, cells were treated with different concentrations of $\mathrm{HNT} / \mathrm{CURBO}$ ranging from 44 to $176 \mu \mathrm{g} / \mathrm{mL}$ and incubated at $37^{\circ} \mathrm{C}$ in $5 \% \mathrm{CO}_{2}$ atmosphere for $24 \mathrm{~h}$. After treatment, cell viability was assayed using 3-(4,5dimethylthiazol-2-yl)-5-(3 carboxymethoxyphenyl)-2(4-sulfophenyl)-2H-tetrazolium (MTS), added to the cells and allowed to develop for $1 \mathrm{~h}$ at $37^{\circ} \mathrm{C}$. Colorimetric measurements were performed at $490 \mathrm{~nm}$ using an ELISA plate reader. The cell viability percentage was expressed by equation: Cell viability $=\left(\mathrm{D}_{\text {sample }} / \mathrm{D}_{\text {control }}\right) \times 100 \%$; where $\mathrm{D}_{\text {sample }}$ and $\mathrm{D}_{\text {control }}$ are the absorbance of the sample and the control.

\section{MTS Assay Chlorpromazine $\mathrm{H}$, Cytochalasin D, Nocodazole and Sodium Azide}

HeLa and Raw 264.7 cells were seeded at a density of $1 \times 10^{4}$ cells per well on 96-well plates and incubated overnight at $37{ }^{\circ} \mathrm{C}$ in $5 \% \mathrm{CO}_{2}$. Afterwards, cells were treated with different concentrations of Cytochalasin D and Nocodazole ranging from $5 \mu \mathrm{M}$ to $20 \mu \mathrm{M}$, Chlorpromazine Hydrochloride ranging from 5 to $10 \mu \mathrm{g} / \mathrm{mL}$, and $\mathrm{NaN}_{3}$ 0.05-0.005\%. Cells were incubated at $37{ }^{\circ} \mathrm{C}$ in $5 \% \mathrm{CO}_{2}$ atmosphere for $2 \mathrm{~h} 30^{\prime}$ and 24h. After treatment, cell viability was assayed using 3-(4,5dimethylthiazol-2-yl)-5-(3 carboxymethoxyphenyl)-2(4-sulfophenyl)-2H-tetrazolium (MTS), added to the cells and allowed to develop for $1 \mathrm{~h}$ at $37^{\circ} \mathrm{C}$. Colorimetric measurements were performed at $490 \mathrm{~nm}$ using an ELISA plate reader.

\section{Statistics MTS Assay}

All experiments were performed in triplicate and repeated at least twice. The results were expressed as mean \pm SEM. The responses were calculated as a percentage compared to the untreated group results.

\section{Inhibition Studies and Distribution of HNT/CURBO in Living Cells}

HeLa cells were seeded at a density of $2 \times 10^{4}$ cells per well on chamber slide for cell culturing and incubated for $24 \mathrm{~h}$ at $37{ }^{\circ} \mathrm{C}$ in $5 \% \mathrm{CO}_{2}$. Subsequently, cells were 
treated for $2 \mathrm{~h} 30^{\prime}$ with Chlorpromazine Hydrochloride $(10 \mu \mathrm{g} / \mathrm{mL})$, Cytochalasin $\mathrm{D}(10 \mu \mathrm{M})$ and Sodium azide $0.005 \%$. Once finished the treatment, cells were washed with phosphate buffer saline $1 \mathrm{X}$ (PBS-1X) and then HNT/CURBO $(88 \mu \mathrm{g} / \mathrm{mL})$ was added for $24 \mathrm{~h}$. Raw 264.7 cells were seeded at a density of $2 \times 10^{4}$ cells per well on chamber slide for cell culturing and incubated for $24 \mathrm{~h}$ at $37{ }^{\circ} \mathrm{C}$ in $5 \% \mathrm{CO}_{2}$. Subsequently, cells were treated for $2 \mathrm{~h} 30^{\prime}$ with Chlorpromazine Hydrochloride $(10 \mu \mathrm{g} / \mathrm{mL})$, Cytochalasin $\mathrm{D}(10 \mu \mathrm{M})$, Nocodazole $(10 \mu \mathrm{M})$ and Sodium azide $0.005 \%$. Once finished the treatment, cells were washed with PBS-1X and then HNT/CURBO $(88 \mu \mathrm{g} / \mathrm{mL})$ was added for $4 \mathrm{~h}$. At the end, cells were washed with PBS-1X and fixed with $4 \%$ paraformaldehyde for 20 minutes. After this passage cells were washed with PBS-1X and nuclei were stained with $1 \mu \mathrm{g} / \mathrm{mL}$ of the nuclear stain Hoechst 33342 (Invitrogen) for 20 minutes. After nuclear staining, cells were further washed with PBS $1 \mathrm{X}$, and the slide was observed under fluorescence microscope.

\section{Hemocompatibility}

In order to evaluate the interaction of nanomaterials with human blood, we employed a procedure reported elsewhere with minor modifications. ${ }^{55}$ Fresh blood was collected from 12 healthy subjects (1:1 men/women). Five milliliters of blood were centrifuged $(1000 \times \mathrm{g} 20$ minutes) and washed with PBS-1X pH $7.4(10 \mathrm{~mL})$ three times, according to completely remove serum and obtain human red blood cells (HRBCs). After that, the HRBCs were diluted with PBS $1 \mathrm{X} \mathrm{pH} 7.4$ solution (1:5). Then, $0.25 \mathrm{~mL}$ of the diluted HRBCs suspension was transferred to a $1.5 \mathrm{~mL}$ Eppendorf tube, which was filled with $0.5 \mathrm{~mL}$ of water (as positive control), PBS $1 \mathrm{X}$ buffer (as negative control), and different concentration of HNT $(10,20,50,100,200$ $\mu \mathrm{g} / \mathrm{mL})$, HNT/CURBO $(10,20,50,100,200 \mu \mathrm{g} / \mathrm{mL})$, CURBO $(1.08,2.16,5.4,10.8,21.6 \mu \mathrm{M})$ and acetonitrile as further control (solvent of CURBO). All the samples were incubated at $37{ }^{\circ} \mathrm{C}$ for $12 \mathrm{~h}$ then centrifuged at $1000 \times \mathrm{g} 4{ }^{\circ} \mathrm{C}$ for 20 minutes. The absorbance at $570 \mathrm{~nm}$ of supernatant liquid was measured with microplate reader. Written informed consent was obtained from each subject. The hemolysis rate was calculated as follows:

$$
\begin{aligned}
& \text { Hemolysis } \\
& \text { ratio }(\%)
\end{aligned}=\frac{\text { Sample absorbance }- \text { Negative control }}{\text { Positive control }- \text { Negative control }} \times 100 \%
$$

\section{Results \\ Biocompatibility of HNT/CURBO on HeLa and Raw 264.7 Cells}

Considering that low cytotoxicity is one of the essential properties of an ideal carrier system, the in vitro effects of the HNT/CURBO hybrid on HeLa and Raw 264.7 cells were investigated by MTS assay prior to internalization studies. The cell viability was examined upon exposure to different concentrations of HNT/CURBO as depicted in Figure 2 for $24 \mathrm{~h}, 48 \mathrm{~h}$ and $72 \mathrm{~h}$. The results reveal that this new nanomaterial, as raw HNT, exhibits low cytotoxicity; viability is almost $80 \%$ for the highest concentration of HNT/CURBO in HeLa cells and close to $100 \%$ in Raw 264.7 following a $24 \mathrm{~h}$ incubation (Figure 2A). Even after treatments of $48 \mathrm{~h}$ (Figure 2B) and 72h (Figure 2C), cell viability remained high for both cell lines. As regards Raw 264.7 macrophages, cell viability values exceeding $100 \%$, demonstrating that HNT/CURBO is not toxic to cells and highly biocompatible. The HNT/CURBO nanomaterial was synthesized by following a procedure previously reported. Briefly, the biocompatible probe was obtained by the loading of CURBO molecules into pristine HNT by vacuum cycling of an HNT suspension in a $\mathrm{MeCN}$ solution of CURBO. Following this procedure, the percent loading of the CURBO into HNT lumen, estimated by thermogravimetric analysis, was ca. $4 \mathrm{wt} \%$. The physicochemical characterization highlighted the successful loading of CURBO into HNTs. FT-IR spectroscopy indeed showed the presence of CURBO characteristic vibration bands in the HNT/CURBO spectrum. The presence of the organic moieties into the lumen was esteemed by morphological studies and by DLS measurements. We estimated a hydrodynamic radius of ca. $340 \mathrm{~nm}$, highlighting the absence of the formation of clusters between the modified nanotubes. Furthermore, solid-state fluorescent measurements showed that the HNT/CURBO emits in both green and red while excited in the blue portion of the electromagnetic spectrum. In order to evaluate the internalization pathway of HNT/CURBO, it is also essential to estimate the cellular toxicity of each of the pharmacological inhibitors. To this end, the cell viability was investigated upon exposure to different concentrations of Cytochalasin D, Chlorpromazine $\mathrm{H}$, Nocodazole and Sodium azide for $2 \mathrm{~h} 30^{\prime}$ (Figures $3 \mathrm{~A}$ and $4 \mathrm{~A}$ ). It is 
A

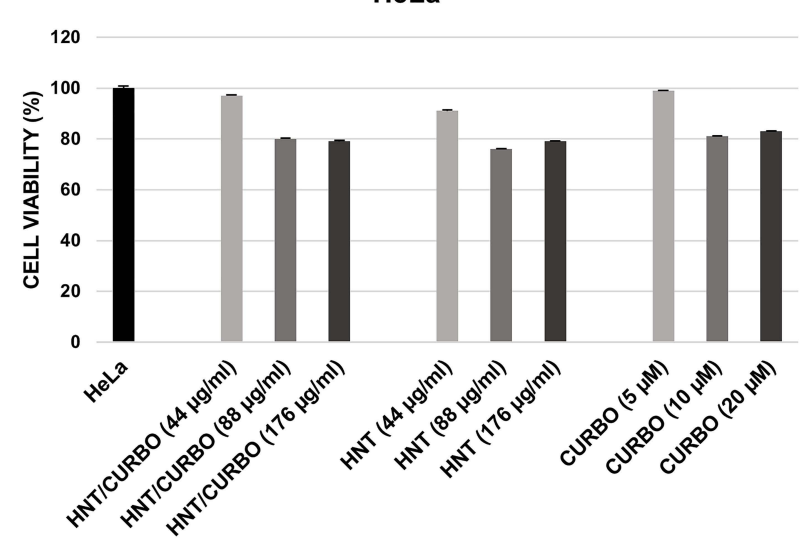

B

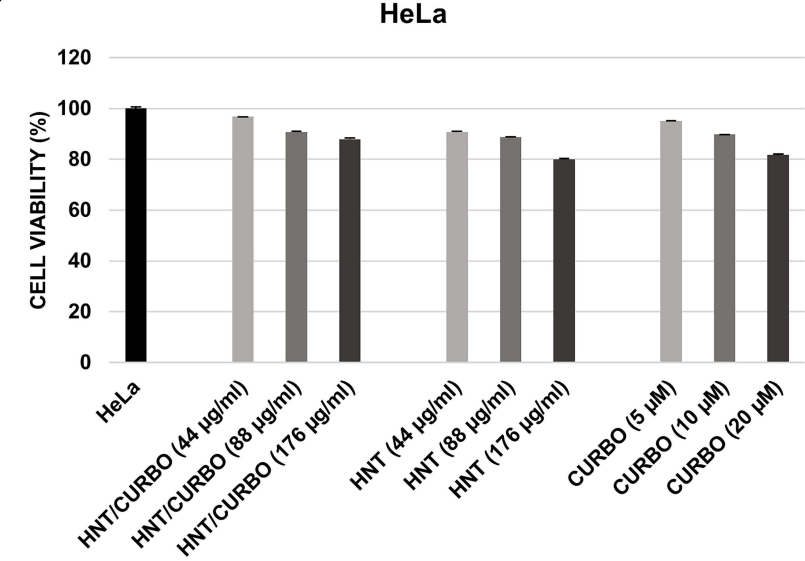

C

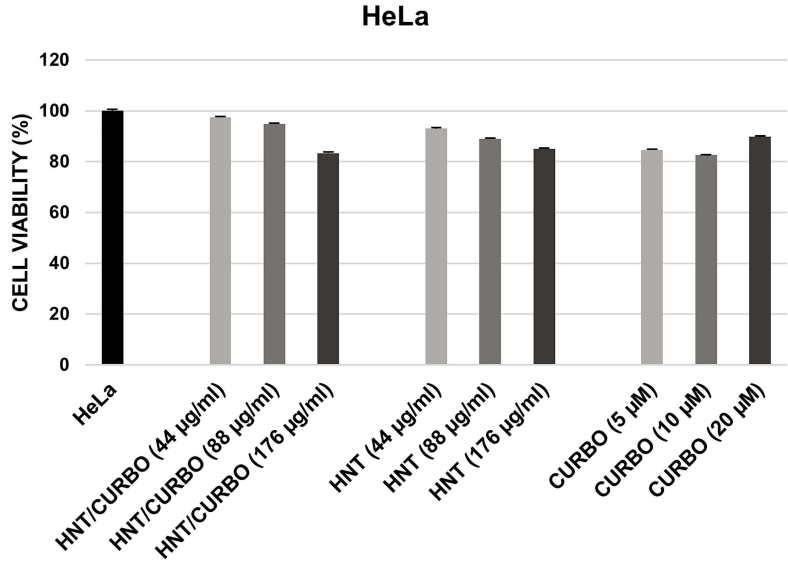

Raw 264.7

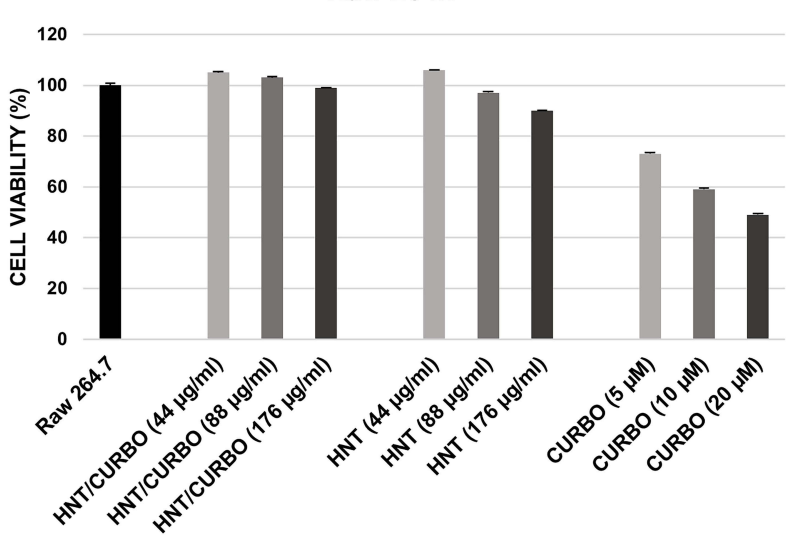

Raw 264.7

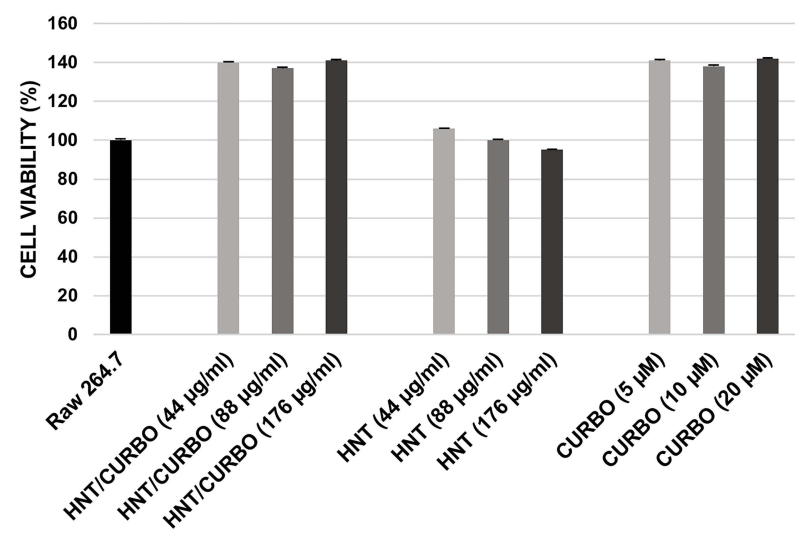

Raw 264.7

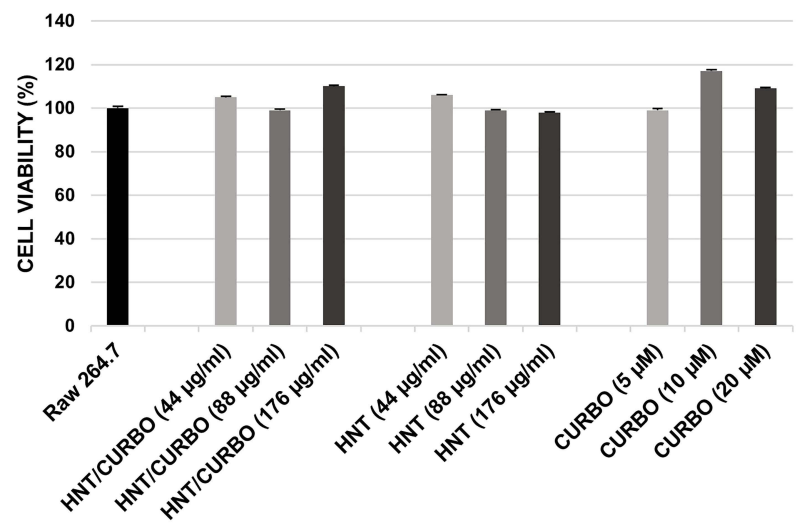

Figure 2 Cell viability assay on HeLa and Raw 264.7 cells. Cells were treated with different concentrations of HNT/CURBO, HNT, and CURBO for 24h (A), 48h (B) and $72 \mathrm{~h}(\mathbf{C})$.

known in the literature that to establish an optimal protocol for their use, it is necessary to evaluate the in vitro cellular toxicity because treatments for prolonged periods of time turn out to be toxic to cells. ${ }^{47}$ As it is possible to observe, as a result of the treatment with inhibitor drugs, there is an alteration in cell morphology, but despite this,
MTS assay confirms that cells are still viable (except for the highest concentration of Chlorpromazine H). In addition, to assess cell viability, cells were also observed under microscope to evaluate possible changes in morphology in response to treatment with these drugs (Figures $3 \mathrm{~B}$ and 4B). Chlorpromazine H $(10 \mu \mathrm{g} / \mathrm{mL})$, Sodium azide 
A

HeLa

120
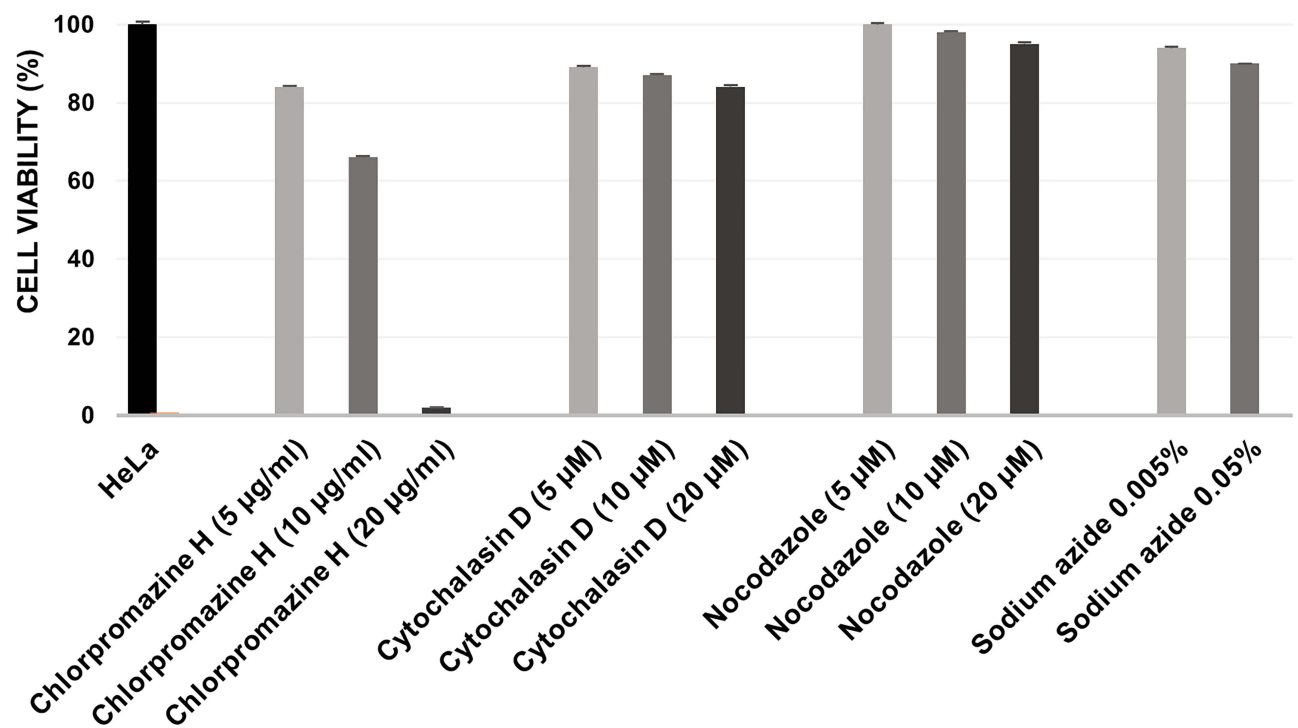

B

$(5 \mu M)$
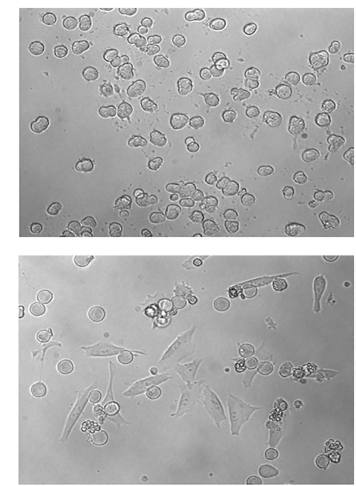

$(5 \mu \mathrm{g} / \mathrm{ml})$

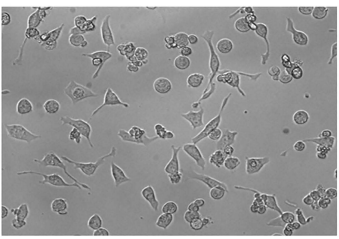

$0.05 \%$

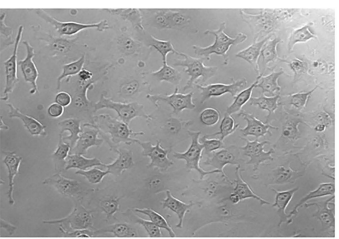

$(10 \mu \mathrm{M})$
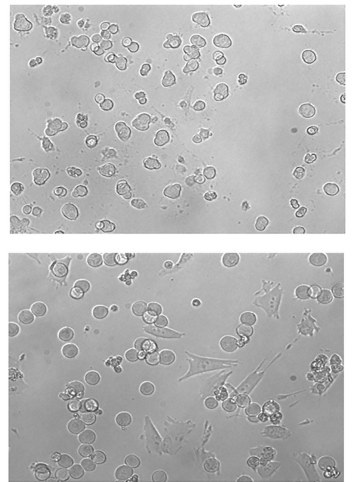

$(10 \mu \mathrm{g} / \mathrm{ml})$

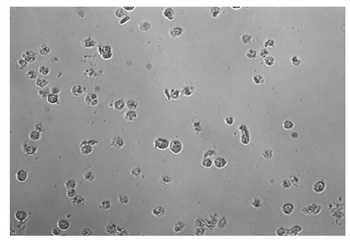

$0.005 \%$

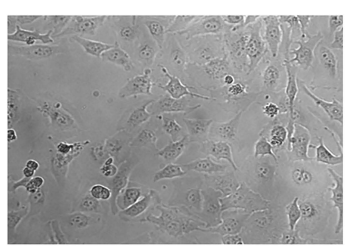

$(20 \mu M)$

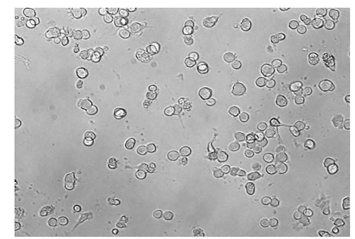

Cytochalasin D

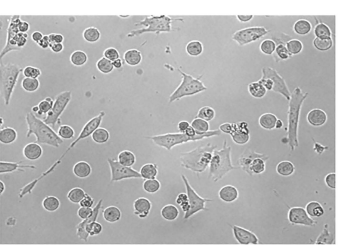

Nocodazole

$(20 \mu \mathrm{g} / \mathrm{ml})$

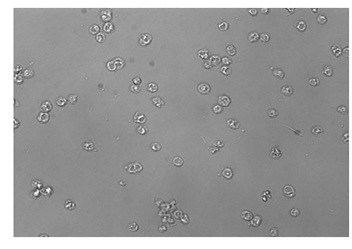

Chlorpromazine $\mathrm{H}$

Sodium azide

Figure 3 (A) Cell viability assay performed on HeLa cells after treatment of $2 \mathrm{~h} 30^{\prime}$ with different concentrations of inhibitory drugs Chlorpromazine $\mathrm{H}$, Cytochalasin $\mathrm{D}$, Nocodazole and Sodium Azide. (B) Microscope images of HeLa cells following the treatment of $2 \mathrm{~h} 30^{\prime}$ with the different concentrations of the inhibitory drugs. 
A

Raw 264.7

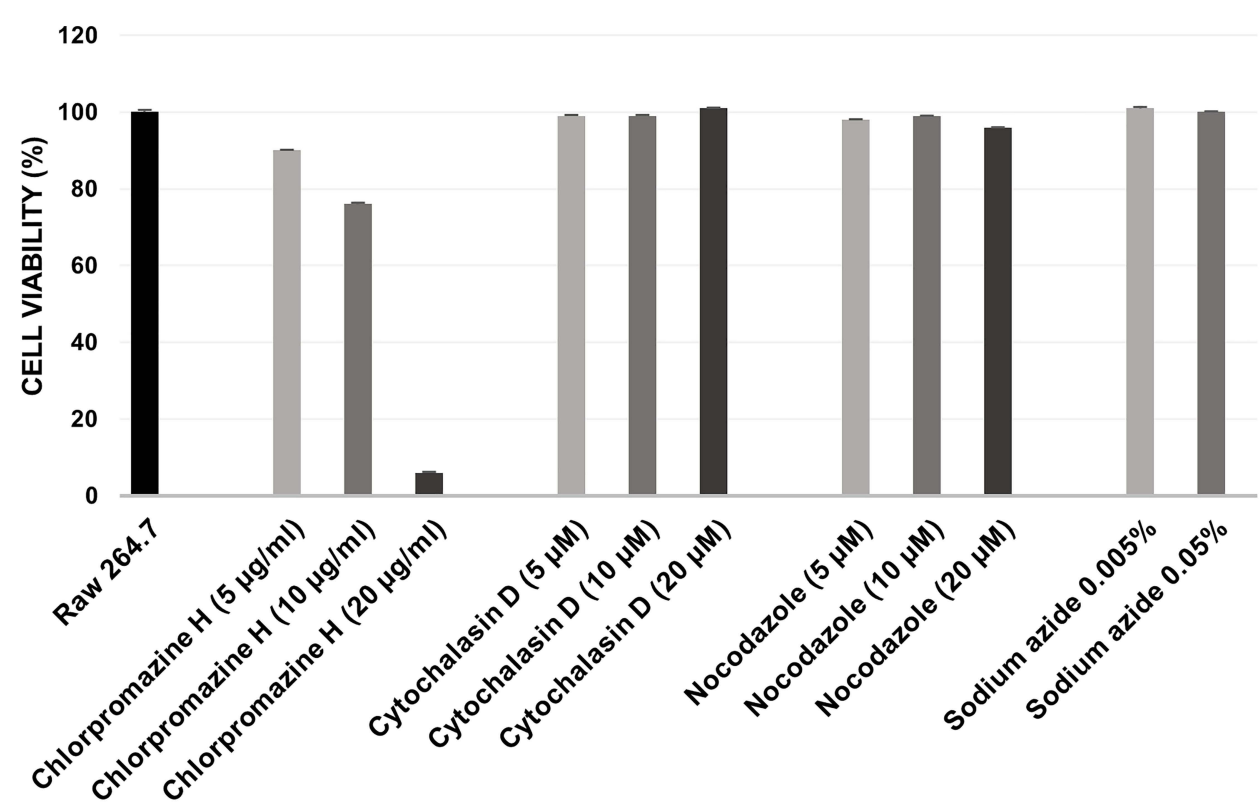

B

$(5 \mu M)$
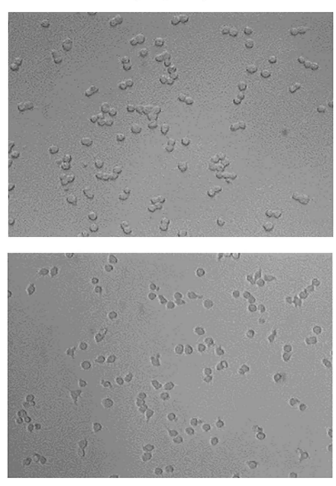

(5 $\mu \mathrm{g} / \mathrm{ml})$

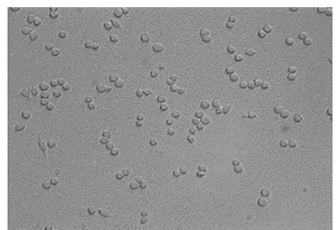

$0.05 \%$

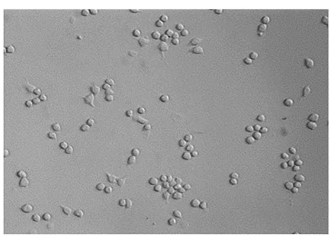

$(10 \mu \mathrm{M})$
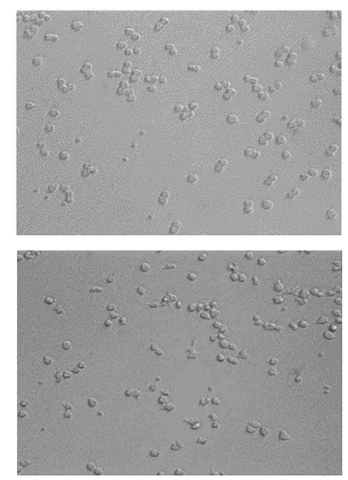

$(10 \mu \mathrm{g} / \mathrm{ml})$

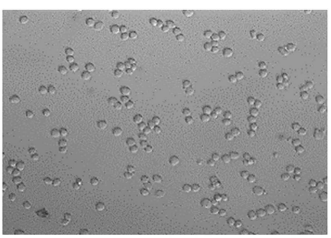

$0.005 \%$

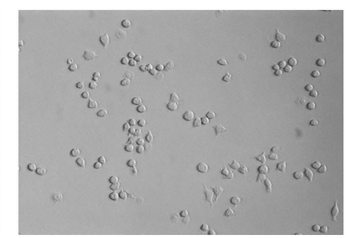

$(20 \mu M)$

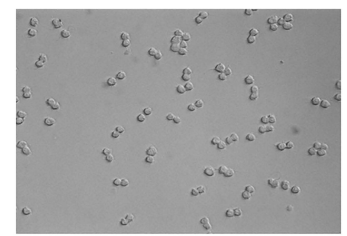

Cytochalasin D

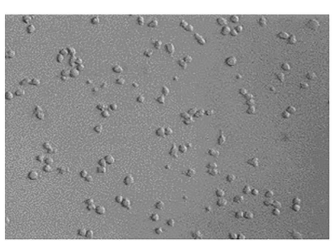

Nocodazole

(20 $\mu \mathrm{g} / \mathrm{ml})$

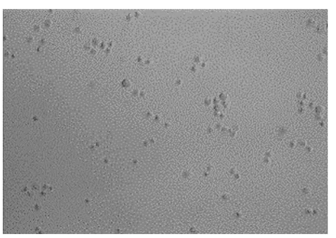

Chlorpromazine $\mathrm{H}$

Sodium azide

Figure 4 (A) Cell viability assay performed on Raw 264.7 cells after treatment of $2 \mathrm{~h} 30^{\prime}$ with different concentrations of inhibitory drugs Chlorpromazine $\mathrm{H}$, Cytochalasin $\mathrm{D}$, Nocodazole and Sodium Azide. (B) Microscope images of Raw 264.7 cells following the treatment of $2 \mathrm{~h} 30^{\prime}$ with the different concentrations of the inhibitory drugs. 
$0.005 \%$, Cytochalasin D and Nocodazole $(10 \mu \mathrm{M})$ were the optimal concentration of drugs to use for inhibition studies.

\section{Inhibition Studies and Distribution of HNT/CURBO in Living Cells}

Before analyzing the possible pathway involved in HNTs cellular uptake, live HeLa and Raw 264.7 cells were incubated with HNT/CURBO and were observed under fluorescence microscope to verify the nanomaterial internalization by cells. HeLa cells were treated for $24 \mathrm{~h}$ with different concentrations of HNT/CURBO, while Raw 264.7 cells were subjected to a $4 \mathrm{~h}$ treatment. Indeed, it is known in literature that macrophages are able to degrade halloysite. ${ }^{56}$ The green fluorescence signal can be clearly seen inside both cell lines (Figure 5A and B) by fluorescence microscopy. Green fluorescent signals inside the cells indicate that the compound can be internalized and that is localized in the cytoplasmic area, particularly in the perinuclear region. In Figure 6 we show that HeLa cells are treated for $24 \mathrm{~h}$ with HNT/ CURBO $(88 \mu \mathrm{g} / \mathrm{mL})$ after pre-treatment of $2 \mathrm{~h} 30^{\prime}$ with different inhibitors. As it is possible to observe, in HeLa cells pre-treated with Sodium azide (Figure 6D), Cytochalasin D (Figure 6E) and Chlorpromazine $\mathrm{H}$ (Figure 6F), there is a considerable reduction in FITC signal inside cells, related to a decrease inside the cells of HNT/CURBO compared to the condition where cells are not treated with inhibitors (Figure 6C). In Figure 6B, control cells were treated with unlabeled HNTs, no fluorescence signals can be detected. Also, in Raw 264.7 cells (Figure 7) pre-treated with Sodium azide (Figure 7D), Cytochalasin D (Figure 7E), Chlorpromazine $\mathrm{H}$ (Figure 7F), and Nocodazole there is a decrease in FITC signal, due to the presence of HNT/CURBO inside the cells, compared to the condition where cells are not treated with inhibitors (Figure 7C). In Figure 7B, Raw 264.7 were treated only with unlabeled HNTs, and as shown, no fluorescence signals can be detected. To analyze the number of internalized nanoparticles under the different conditions, we used the "ImageJ" software, which allowed us to analyze the fluorescence given by HNT/CURBO inside the cells following treatment with the different drugs Sodium azide, Cytochalasin D, Chlorpromazine $\mathrm{H}$ and Nocodazole, compared to the control. We analyzed a different number of fields $(n=6)$ for each condition, the columns marked with $(*)$ in
Figure 8 indicate that there is a significant statistical difference $(\mathrm{p}<0.01)$ in fluorescence between cells without treatment and those treated with the different inhibitors. The result for Hela cells (Figure 8A) shows that HNT/CURBO is internalized into cells by energydependent manner. In fact, when cells are treated with Sodium azide $0.005 \%$ there is a significant reduction of HNT/CURBO internalization. It is also evident that Chlorpromazine hydrochloride and Cytochalasin D are able to greatly inhibit clathrin-mediated endocytosis and clathrin/caveolin-independent endocytosis, respectively. Even in Raw 264.7 cells (Figure 8B), HNT/CURBO internalization is primarily dependent by energy (condition with Sodium azide). Even the presence of other inhibitors reduces the cellular uptake of HNT/CURBO. In particular, in this cell line also, Nocodazole reduces the cellular uptake of HNT/CURBO, indicating that microtubules also participate in the cellular trafficking of this nanomaterial. We can therefore conclude that in macrophage cells, HNT/CURBO internalization depends on clathrin-mediated endocytosis and phagocytosis.

\section{Hemocompatibility}

As regard the nanomaterials for applications in the biomedical field, it is important to verify their haemolytic potency when contacting the blood. In this study, we investigate the effects on Human Red Blood Cells (HRBCs) exposed to pristine halloysite and $\mathrm{HNT} / \mathrm{CURBO}$ for $24 \mathrm{~h}$ at $37^{\circ} \mathrm{C}$. After exposure to different concentrations (Figure 9), a nonnoticeable haemolytic event can be observed, except for the positive control (water). To quantify the hemolytic effect of each concentration of HNT and HNT/CURBO on HRBCs, absorbance of the supernatant at 570 was measured. This provides us with an indication of a possible red blood cells membrane damage. Looking at the results, it is evident that there is a significant difference in the absorbance at 570 $\mathrm{nm}$, associated with red blood cells (RBCs) membrane damage and release of haemoglobin, between the positive control (RBCs exposed to water) and condition treated with different concentrations of HNT - HNT/CURBO. The hemolysis percentage values induced by exposition of HRBCs to different concentrations of HNT/CURBO (Figure 9B) were all less than 5\%. This result suggests that the nanomaterial does not exhibit a significant haemolytic effect, also in relation to pristine HNT (Table 1), conforming to the national biological material hemolysis rate security specified requirements. 

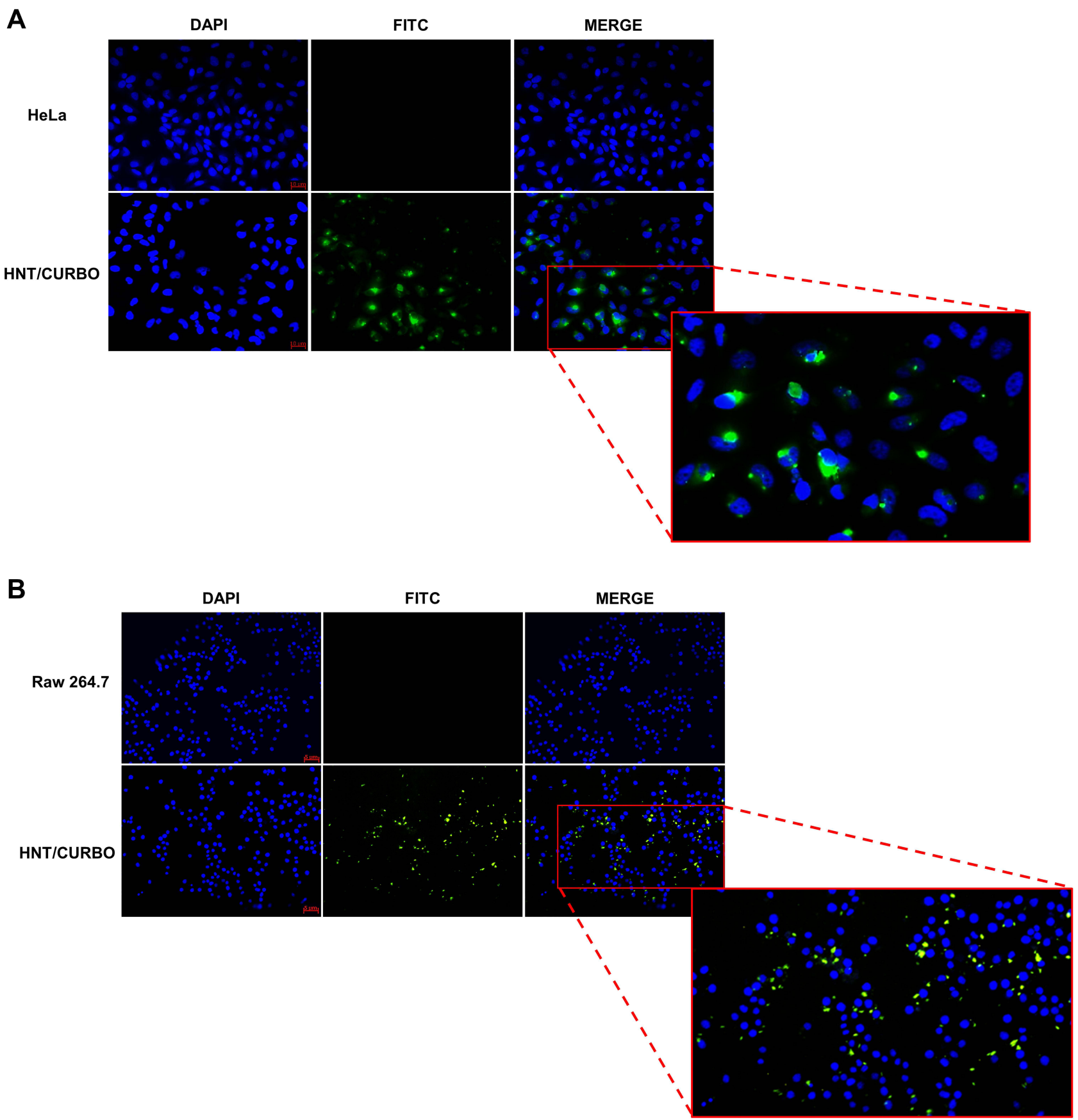

Figure 5 Fluorescence microscopy images. (A) HeLa cells treated for $24 \mathrm{~h}$ with HNT/CURBO at a final concentration of $88 \mu \mathrm{g} / \mathrm{mL}$. Scale bar: $10 \mu \mathrm{m}$, magnification $20 \times(B)$ Raw 264.7 cells treated for $4 \mathrm{~h}$ with HNT/CURBO at a final concentration of $88 \mu \mathrm{g} / \mathrm{mL}$. The nuclei are highlighted in blue (DAPI), and HNT/CURBO in green (FITC) which is localized in the perinuclear region. Scale bar: $5 \mu \mathrm{m}$, magnification 20x.

\section{Discussion}

The mechanism by which HNTs are internalized could be dependent, not only on the properties of HNTs but also on the phagocytic nature of cells. Since surface charge could affect the ability of internalization and the uptake mechanisms, $\zeta$ potential of HNT/CURBO was measured after Halloysite modification and it turned out to be still negative. Furthermore, the release of the fluorescent probe from the lumen of the tube is very slow. The study of release kinetics of CURBO from the lumen of the nanotubes, at different time intervals in phosphatebuffered saline (PBS) at $\mathrm{pH} 7.4$, revealed that after about $8 \mathrm{~h}$ the release percentage is equal to $4.6 \%$ and that this remains constant after $24 \mathrm{~h} .{ }^{28}$ Therefore, the HNT/CURBO 
HeLa

DAPI

\section{A}

HNT

$(88 \mu \mathrm{g} / \mathrm{ml})$

HNT/CURBO

$(88 \mu \mathrm{g} / \mathrm{ml})$

\section{Sodium azide $0.005 \%+$ HNT/CURBO}

\section{Chlorpromazine $\mathrm{H}(10 \mu \mathrm{g} / \mathrm{ml})+$ HNT/CURBO}

\section{Cytochalasin D $(10 \mu \mathrm{M})+$ HNT/CURBO}

$\begin{array}{lll}\text { DAPI } & \text { FITC MERG }\end{array}$
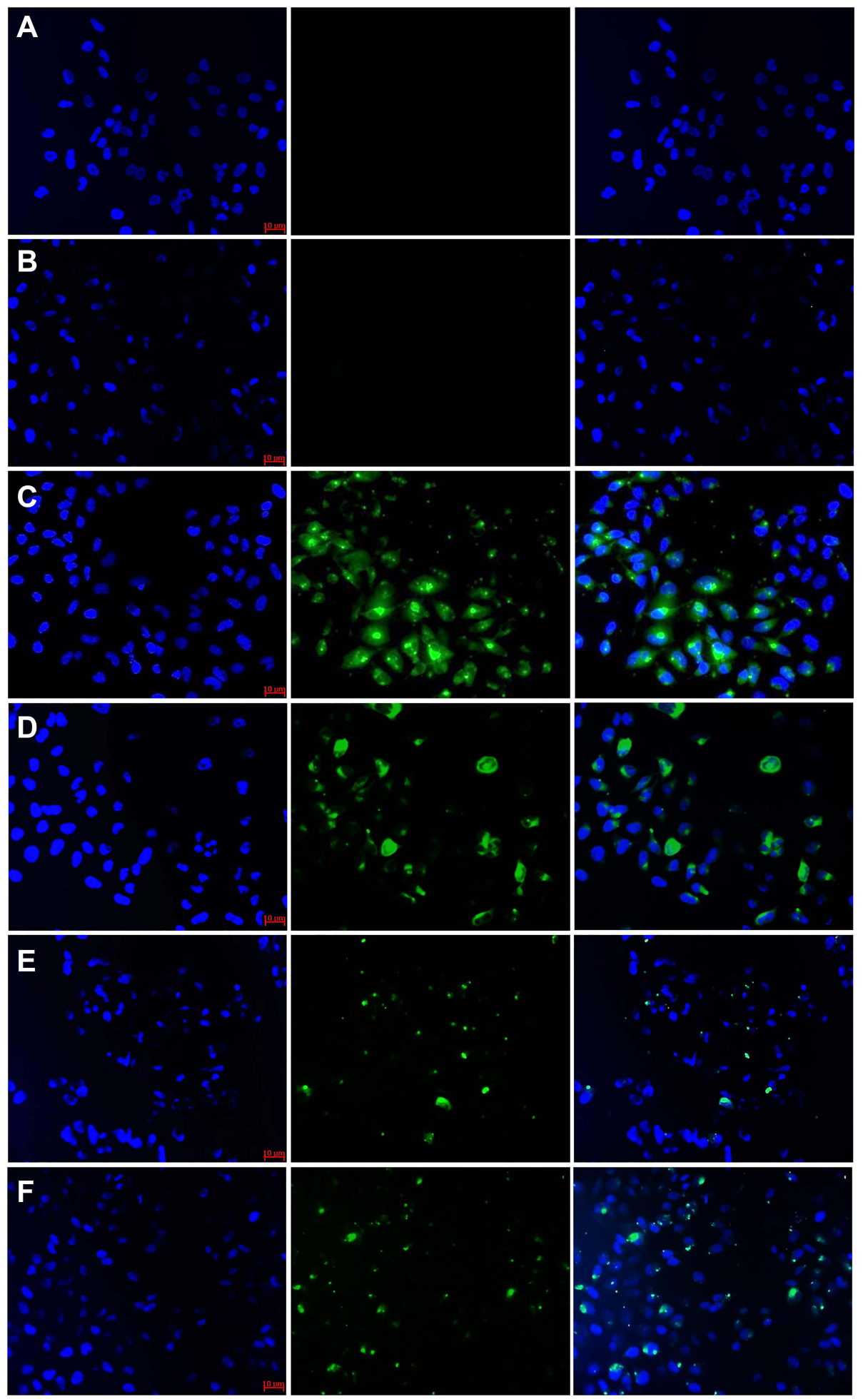
Figure 6 Inhibition of HNT/CURBO internalization in HeLa cells. (A) Untreated HeLa cells; (B) HeLa cells treated for $24 \mathrm{~h}$ with pristine HNT (88 $\mu$ g/mL); (C) HeLa cells
treated for $24 \mathrm{~h}$ with HNT/CURBO $(88 \mu \mathrm{g} / \mathrm{mL})$; HeLa cells treated with: (D) Sodium azide $(0.005 \%)$; (E) Cytochalasin D (I0 $\mu \mathrm{M}) ;(\mathbf{F}) \mathrm{Chlorpromazine} \mathrm{H} \mathrm{(I0 \mu g/mL)} \mathrm{for} 2 \mathrm{~h}$ $30^{\prime}$ and then with HNT/CURBO $(88 \mu \mathrm{g} / \mathrm{mL})$ for $24 \mathrm{~h}$. The nuclei are highlighted in blue (DAPI), and HNT/CURBO in green (FITC), which is localized in the perinuclear region. Scale bar: $10 \mu \mathrm{m}$, magnification $20 \mathrm{x}$.

could be used as an efficient imaging agent for biological purposes. Furthermore, due to the localization of the fluorescent probe into the HNT lumen, the developed system can be similar to pristine HNT since its external surface is unmodified. The latter could be crucial to investigate the halloysite uptake mechanism. With this idea in mind, both 


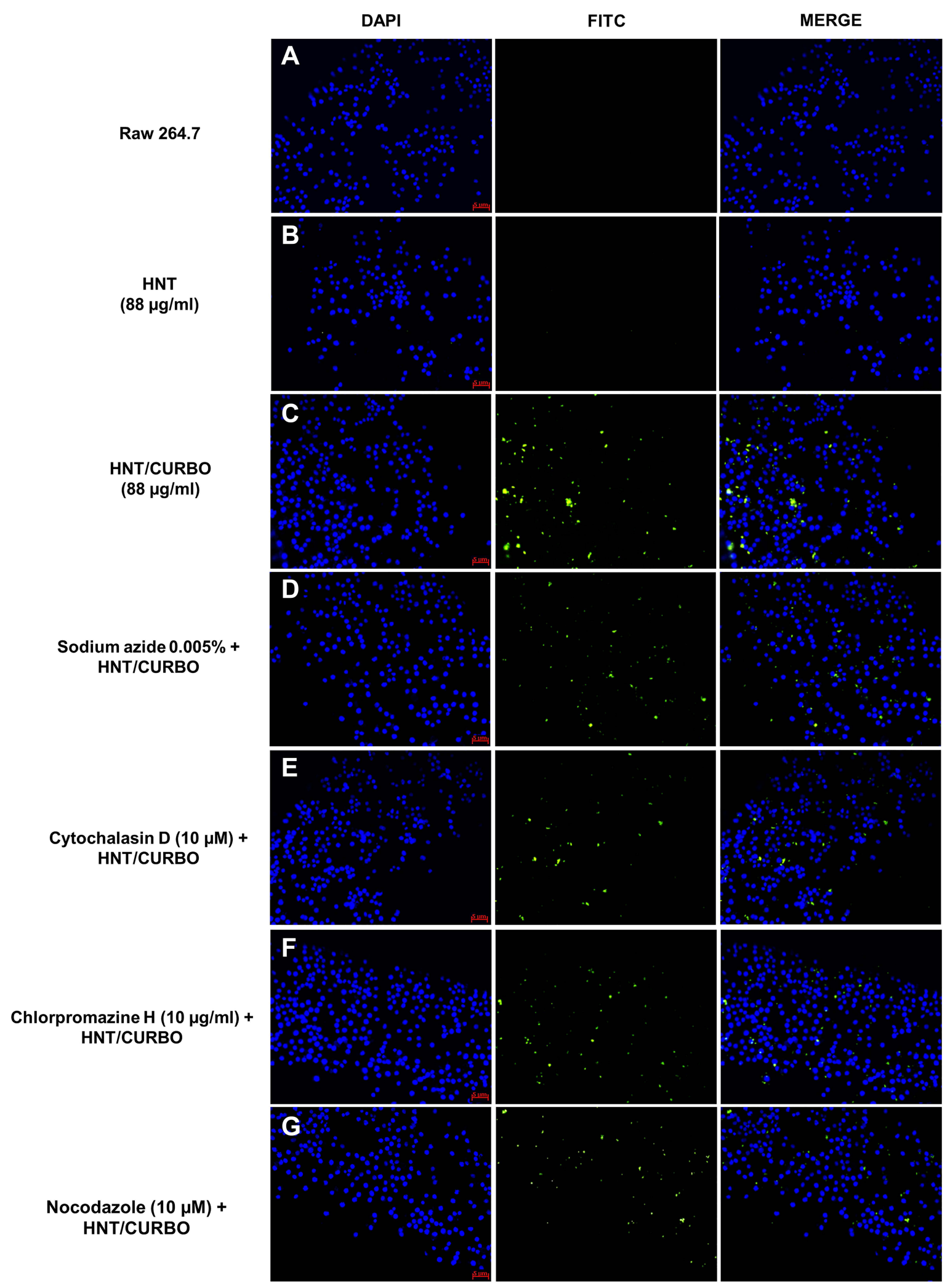

Figure 7 Inhibition of HNT/CURBO internalization in Raw 264.7 cells. (A) Untreated Raw 264.7 cells; (B) Raw 264.7 cells treated for 4 h with pristine HNT (88 $\mu$ g/mL); (C) Raw 264.7 cells treated for 4h with HNT/CURBO (88 $\mu \mathrm{g} / \mathrm{mL})$; Raw 264.7 cells treated with: (D) Sodium azide (0.005\%); (E) Cytochalasin D (I0 $\mu$ M); (F) Chlorpromazine H $(10 \mu \mathrm{g} / \mathrm{mL})$; $(\mathbf{G})$ Nocodazole $(10 \mu \mathrm{M})$ for $2 \mathrm{~h} 30^{\prime}$ and then with HNT/CURBO (88 $\left.\mu \mathrm{g} / \mathrm{mL}\right)$ for $4 \mathrm{~h}$. The nuclei are highlighted in blue (DAPI), and HNT/CURBO in green (FITC), which is localized in the perinuclear region. Scale bar: $5 \mu \mathrm{m}$, magnification $20 \mathrm{x}$. 

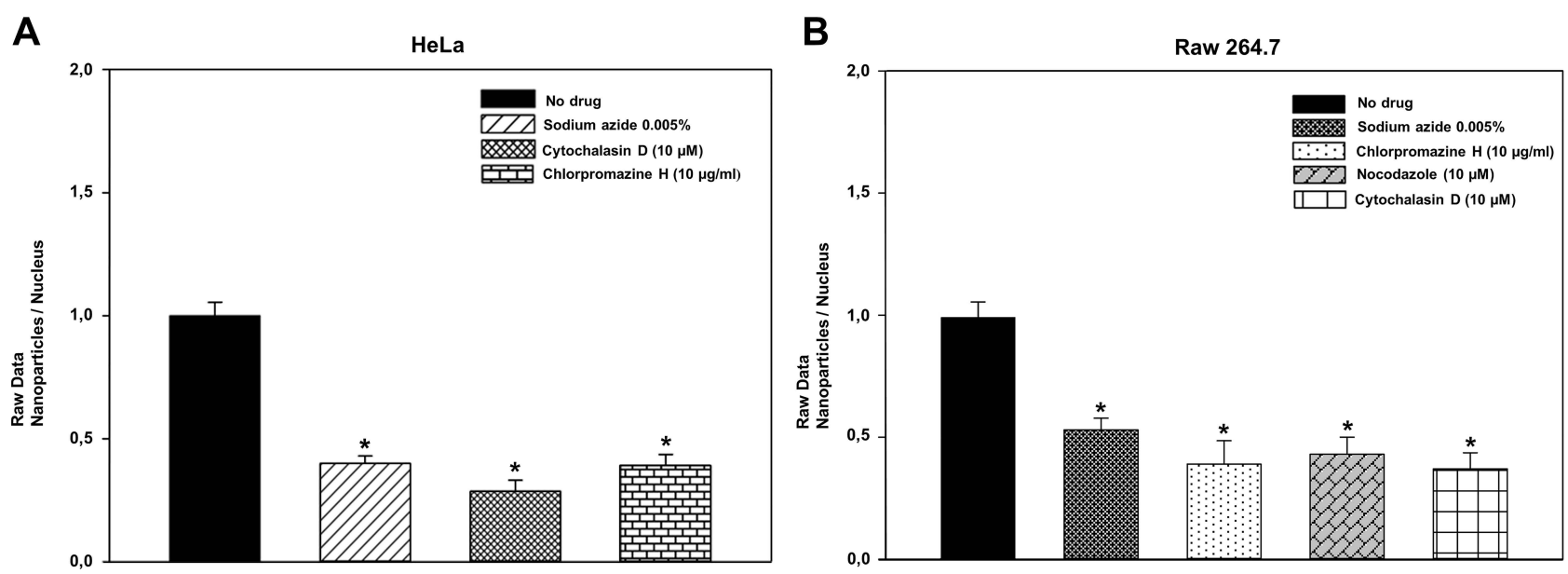

Figure 8 Quantitative analysis of cellular uptake of HNT/CURBO in the presence of various inhibitors in HeLa (A) and Raw $264.7(\mathbf{B})$ cells. The column marked with * ( $<<$ $0.0 \mathrm{I}$ ) indicates that there is a significant statistical difference in fluorescence signal between treated and untreated cells.

A

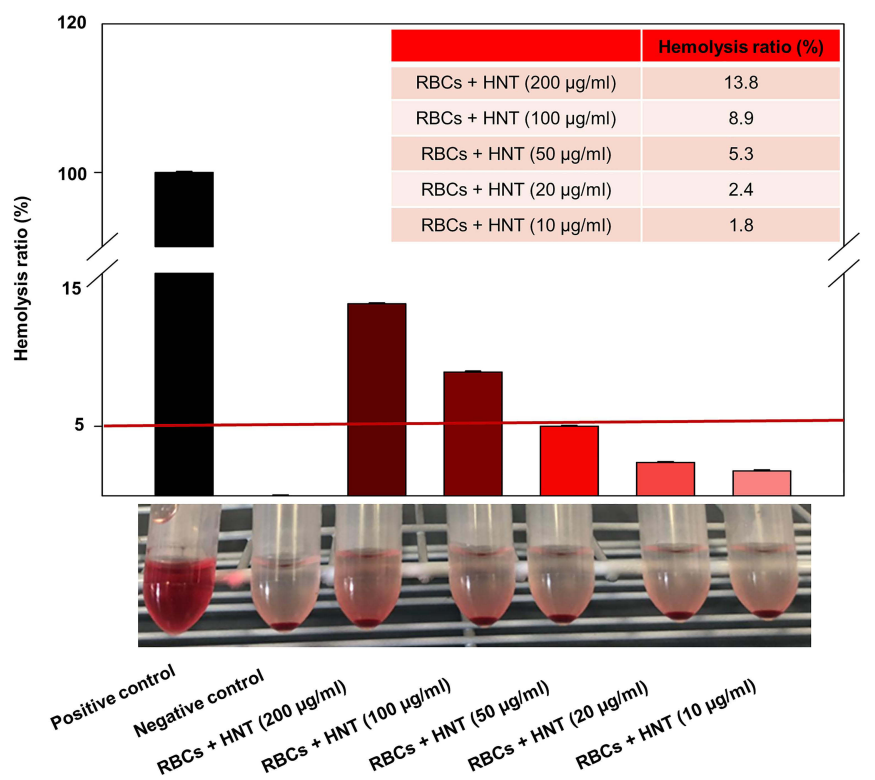

B

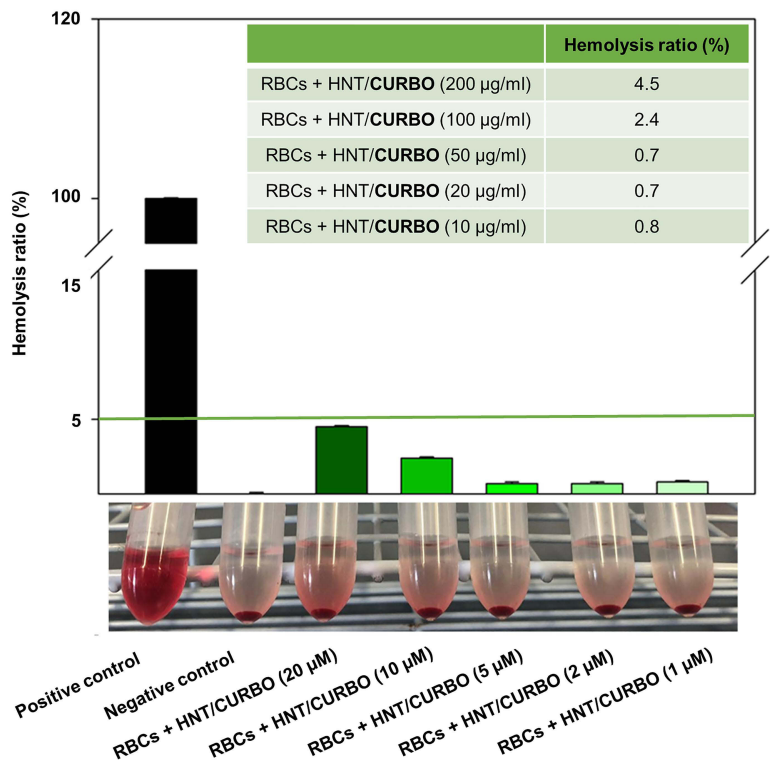

Figure 9 In vitro hemocompatibility assay of (A) raw HNT and (B) HNT/CURBO after incubation at $37^{\circ} \mathrm{C}$ for $12 \mathrm{~h}$. The positive control is in ultrapure water (I00\% lysis), and negative control is in PBS IX (0\% lysis).

non-phagocytic and phagocytic cells were used as models. In particular, we chose HeLa cells (human epithelial adenocarcinoma cell line) and Raw 264.7 (murine macrophage cell line) cells which are often used as a model for primary macrophages. ${ }^{29}$ As regard the nanomaterials for applications in biomedical field, it is important to verify their biocompatibility and their hemolytic potency when in contact with blood. MTS assay demonstrated that HNT/ CURBO is not cytotoxic and that is highly biocompatible for both cell lines. In addition, the nanomaterial does not exhibit an appreciable haemolytic effect. Based on the information obtained by fluorescence microscopy, it is clear that the HNT/CURBO hybrid system can enter in the cytoplasm of living cells. The transport process of the hybrid starts probably with a cell membrane interaction and continues in energy-dependent internalization in both cell lines. In particular, in HeLa cells, clathrin-dependent and independent endocytosis are involved. In Raw 264.7 cells, in addition to phagocytosis and clathrin-dependent endocytosis, microtubules also participate in the cellular trafficking of HNT/CURBO. We can therefore say that there is a combination of several endocytic mechanisms 
Table I Hemolysis ratio (\%) of Human Red Blood Cells (HRBCs) exposed to different concentrations of HNT and HNT/CURBO, obtained from the average of the values resulting from the 12 samples tested

\begin{tabular}{|l|l|}
\hline Samples & Hemolysis Ratio (\%) \\
\hline Positive control & 100 \\
Negative control & 0 \\
RBCs + HNT $(200 \mu \mathrm{g} / \mathrm{mL})$ & 13.8 \\
RBCs + HNT $(100 \mu \mathrm{g} / \mathrm{mL})$ & 8.9 \\
$\mathrm{RBCs}+\mathrm{HNT}(50 \mu \mathrm{g} / \mathrm{mL})$ & 5.3 \\
$\mathrm{RBCs}+\mathrm{HNT}(20 \mu \mathrm{g} / \mathrm{mL})$ & 2.4 \\
$\mathrm{RBCs}+\mathrm{HNT}(10 \mu \mathrm{mL})$ & 1.8 \\
$\mathrm{RBCs}+\mathrm{HNT} / \mathrm{CURBO}(200 \mu \mathrm{g} / \mathrm{mL})$ & 4.5 \\
$\mathrm{RBCs}+\mathrm{HNT} / \mathrm{CURBO}(100 \mu \mathrm{g} / \mathrm{mL})$ & 2.4 \\
$\mathrm{RBCs}+\mathrm{HNT} / \mathrm{CURBO}(50 \mu \mathrm{g} / \mathrm{mL})$ & 0.7 \\
$\mathrm{RBCs}+\mathrm{HNT} / \mathrm{CURBO}(20 \mu \mathrm{g} / \mathrm{mL})$ & 0.7 \\
$\mathrm{RBCs}+\mathrm{HNT} / \mathrm{CURBO}(10 \mu \mathrm{g} / \mathrm{mL})$ & 0.8 \\
\hline
\end{tabular}

involved in the uptake of HNT/CURBO in both the epithelial cells and macrophages. The relatively wide range of sizes for HNTs may be the reason why the internalization of HNTs is mediated by more than one cellular uptake pathways. ${ }^{57,58}$

\section{Conclusion}

Understanding the cellular transport pathways of HNTs may help in the rational design of novel drug delivery systems and may be of great value for their applications in biotechnology. Thanks to the high biocompatibility, HNT/CURBO could be a valuable system for drug delivery and future applications in the biomedical field. The predominantly perinuclear localization, as a result of cellular internalization, leads us to believe that halloysite nanotubes could be excellent allies for intracellular drug delivery.

\section{Disclosure}

The authors report no conflicts of interest in this work.

\section{References}

1. Liu HY, Du L, Zhao YT, et al. In vitro hemocompatibility and cytotoxicity evaluation of halloysite nanotubes for biomedical application. J Nanomater. 2015;16:1-9.

2. Prishchenko DA, Zenkov EV, Mazurenko VV, et al. Molecular dynamics of the halloysite nanotubes. Phys Chem Chem Phys. 2018;20:5841-5849.

3. Santos AC, Ferreira C, Veiga F, et al. Halloysite clay nanotubes for life sciences applications: from drug encapsulation to bioscaffold. $A d v$ Colloid Interface Sci. 2018;257:58-70.
4. Hasani M, Abdouss M, Shojaei S. Nanocontainers for drug delivery systems: a review of Halloysite nanotubes and their properties. Int $J$ Artif Organs. 2020.

5. Liu M, Jia Z, Jia D, et al. Recent advance in research on Halloysite nanotubes-polymer nanocomposite. Prog Polym Sci. 2014;39: 1498-1525.

6. Lvov YM, DeVilliers MM, Fakhrullin RF. The application of halloysite tubule nanoclay in drug delivery. Expert Opin Drug Deliv. 2016;7:977-986.

7. Massaro M, Cavallaro G, Colletti CG, et al. Chemical modification of halloysite nanotubes for controlled loading and release. $J$ Mater Chem B. 2018;6:3415-3433.

8. Vergaro V, Abdullayev E, Lvov YM, et al. Cytocompatibility and uptake of halloysite Clay Nanotubes. Biomacromolecules. 2010; 11:820-826.

9. Kamalieva RF, Ishmukhametov IR, Batasheva SN, et al. Uptake of halloysite clay nanotubes by human cells: colourimetric viability tests and microscopy study. Nano-Structures Nano-Objects. 2018;15: 54-60.

10. Long $\mathrm{Z}, \mathrm{Wu} \mathrm{YP}, \mathrm{Gao} \mathrm{HY}$, et al. In vitro and in vivo toxicity evaluation of halloysite nanotubes. J Mater Chem B. 2018;6:7204-7216.

11. Wang X, Gong J, Gui Z, et al. Halloysite nanotubes-induced Al accumulation and oxidative damage in liver of mice after 30-day repeated oral administration. Environ Toxicol. 2018;33:623-630.

12. Santos AC, Pereira I, Reis S, et al. Biomedical potential of clay nanotube formulations and their toxicity assessment. Expert Opin Drug Deliv. 2019;16:1169-1182.

13. Wu H, Shi Y, Huang C, et al. Multifunctional nanocarrier based on clay nanotubes for efficient intracellular siRNA delivery and gene silencing. J BiomaterAppl. 2014;28:1180-1189.

14. Cavallaro G, Lazzara G, Massaro M, et al. Biocompatible Poly ( $N$-isopropylacrylamide)-halloysite nanotubes for thermoresponsive curcumin release. J Phys Chem. 2015;119:8944-8951.

15. Dzamukova MR, Naumenko EA, Lvov YM, et al. Enzyme-activated intracellular drug delivery with tubule clay nanoformulation. Sci Rep. 2015;5:10560.

16. Massaro M, Piana S, Colletti CG, et al. Multicavity halloysite-amphiphilic cyclodextrin hybrids for co-delivery of natural drugs into thyroid cancer cells. J Mater Chem B. 2015;3:4074-4081.

17. Massaro M, Noto R, Riela S. Past, present and future perspectives on halloysite clay minerals. Molecules. 2020;25:4863.

18. Massaro M, Buscemi G, Arista L, et al. Multifunctional carrier based on halloysite/laponite hybrid hydrogel for kartogenin delivery. $A C S$ Med Chem Lett. 2019a; 104:419-424.

19. Rawtani D, Pandey G, Tharmavaram M, et al. Development of a novel "nanocarrier" system based on Halloysite Nanotubes to overcome the complexation of ciprofloxacin with iron: an in vitro approach. Appl Clay Sci. 2017;150:293-302.

20. Massaro M, Barone G, Biddeci G, et al. Halloysite nanotubes-carbon dots hybrids multifunctional nanocarrier with positive cell target ability as a potential non-viral vector for oral gene therapy. J Colloid Interface Sci. 2019b;552:236-246.

21. Pandey G, Munguambe DM, Tharmavaram M, et al. Halloysite nanotubes - An efficient "nano-support" for the immobilization of $\alpha$ amylase. Appl Clay Sci. 2017;136:184-191.

22. Saadat S, Pandey G, Tharmavaram M, et al. Nano-interfacial decoration of Halloysite Nanotubes for the development of antimicrobial nanocomposites. Adv Colloid Interface Sci. 2019;102063.

23. Tharmavaram M, Pandey G, Rawtani D. Surface modified halloysite nanotubes: a flexible interface for biological, environmental and catalytic applications. Adv Colloid Interface Sci. 2018;261:82-101.

24. Rawtani D, Agrawal YK. A study of the behavior of HNT with DNA intercalator acridine orange. BioNanoScience. 2012;3:52-57.

25. Rawtani D, Agrawal YK, Prajapati P. Interaction Behavior of DNA with halloysite nanotube-silver nanoparticle-based composite. BioNanoScience. 2013;3:73-78. 
26. Foroozandeh P, Aziz AA. Insight into cellular uptake and intracellular trafficking of nanoparticles. Nanoscale Res Lett. 2018;13: 339-351.

27. Liu H, Wang ZG, Liu SL, et al. Intracellular pathway of halloysite nanotubes: potential application for antitumor drug delivery. J Mater Sci. 2019;54:693-704.

28. Riela S, Barattucci A, Barreca D, et al. Boosting the properties of a fluorescent dye by encapsulation into halloysite nanotubes. Dyes Pigments. 2021;187:109094.

29. Merly L, Smith SL. Murine RAW 264.7 cell line as an immune target: are we missing something? Immunopharmacol Immunotoxicol. 2017;39:55-58.

30. McMahon HT, Gallop JL. Membrane curvature and mechanisms of dynamic cell membrane remodelling. Nature. 2005;438:590-596.

31. Blazek AD, Paleo BJ, Weisleder N. Plasma membrane repair: a central process for maintaining cellular homeostasis. Physiology (Bethesda). 2015;30:38-448.

32. Watson H. Biological membranes. Essays Biochem. 2015;59:43-69.

33. Ernst R, Ballweg S, Levental I. Cellular mechanisms of physicochemical membrane homeostasis. Curr Opin Cell Biol. 2018;53: 44-51.

34. Conner SD, Schmid SL. Regulated portals of entry into the cell. Nature. 2003;422:37-44.

35. Yang NJ, Hinner MJ. Getting across the cell membrane: an overview for small molecules, peptides, and proteins. Methods Mol Biol. 2015;1266:29-53.

36. Behzadi S, Serpooshan V, Tao W, et al. Cellular uptake of nanoparticles: journey inside the cell. Chem Soc Rev. 2017;46:4218-4244.

37. Allen LA, Aderem A. Mechanisms of phagocytosis. Current Opinion Immunol. 1996;8:36-40.

38. Aderem A, Underhill DM. Mechanism of phagocytosis in macrophage. Annu Rev Immunol. 1999;17:593-623.

39. Doherty GJ, McMahon HT. Mechanism of endocytosis. Annu Rev Biochem. 2009;78:857-902.

40. Howes MT, Mayor S, Parton RG. Molecules, mechanisms, and cellular roles of clathrin-independent endocytosis. Curr Opin Cell Biol. 2010;22:519-527.

41. McMahon HT, Boucrot E. Molecular mechanism and physiological functions of clathrin-mediated endocytosis. Nat Rev Mol Cell Biol. 2011;12:517-533.

42. Tsubaki M, Yoshikawa S. Fourier-transform infra-red study of azide binding to the $\mathrm{Fe} 3-\mathrm{CuB}$ binuclear site of bovine cytochrome oxidase: implication of the redox-linked conformational change at the binuclear site. Biochem. 1993;32:174-182.
43. Gribble FM, Ashfield R, Ammala C, et al. Properties of cloned ATP-sensitive $\mathrm{K}+$ currents expressed in Xenopus oocytes. J Physiol. 1997;498:87-98.

44. Harvey J, Hardy SC, Ashford MLJ. Dual actions of the metabolic inhibitor, sodium azide on KATP channel currents in the rat CRI-G1 insulinoma cell line. Br J Pharmacol. 1999;126:51-60.

45. Kostarelos K, Lacerda L, Pastorin G, et al. Cellular uptake of functionalized carbon nanotubes is independent of functional group and cell type. Nat Nanotechnol. 2007;2:108-113.

46. Wang LH, Rothberg KG, Anderson RG. Mis-assembly of clathrin lattices on endosomes reveals a regulatory switch for coated pit formation. J Cell Biol. 1993;123:1107-1117.

47. Vercauteren D, Vandenbroucke RE, Jones AT, et al. The use of inhibitors to study endocytic pathways of gene carriers: optimization and pitfalls. Mol Ther. 2010;18:561-569.

48. Dombu CY, Kroubi M, Zibouche R, et al. Characterization of endocytosis and exocytosis of cationic nanoparticles in airway epithelium cells. Nanotechnology. 2010;21:355102.

49. Schliwa M. Action of cytochalasin D on cytoskeletal networks. J Cell Biol. 1982;92:79-91.

50. Cooper JA. Effects of cytochalasin and phalloidin on actin. J Cell Biol. 1987;105:1473-1478.

51. Fujimoto LM, Roth R, Heuser JE, Schmid SL. Actin assembly plays a variable, but not obligatory role in receptor-mediated endocytosis in mammalian cells. Traffic. 2000;1:161-171.

52. Dutta D, Donaldson JG. Search for inhibitors of endocytosis. Cell Logist. 2012;2:203-208.

53. Kumari S, Swetha S, Mayor S. Endocytosis unplugged multiple ways to enter the cell. Cell Res. 2010;20:256-275.

54. Hanania R, Sun HS, Xu K, et al. Classically activated macrophages use stable microtubules for matrix Metalloproteinase-9 (MMP-9) Secretion. J Biol Chem. 2012;287:8468-8483.

55. Liu M, Chang Y, Yang J, et al. Functionalized halloysite nanotube by chitosan grafting for drug delivery of curcumin to achieve enhanced anticancer efficacy. J Mater Chem B. 2016;4:2253-2263.

56. Massaro M, Lazzara G, Noto R, Riela S. Halloysite nanotubes: a green resource for materials and life sciences. Rend Fis Acc Lincei. 2020;31:213-221.

57. Kam NWS, Liu Z, Dai H. Carbon nanotubes as intracellular transporters for proteins and DNA: an investigation of the uptake mechanism and pathway. Angew Chem Int. 2006;118:591-595.

58. Hillaireau H, Couvreur P. Nanocarriers' entry into the cell: relevance to drug delivery. Cell Mol Life Sci. 2009;66:2873-2896.
International Journal of Nanomedicine

\section{Publish your work in this journal}

The International Journal of Nanomedicine is an international, peerreviewed journal focusing on the application of nanotechnology in diagnostics, therapeutics, and drug delivery systems throughout the biomedical field. This journal is indexed on PubMed Central, MedLine, CAS, SciSearch ${ }^{\circledR}$, Current Contents ${ }^{\mathbb{B}} /$ Clinical Medicine,
Journal Citation Reports/Science Edition, EMBase, Scopus and the Elsevier Bibliographic databases. The manuscript management system is completely online and includes a very quick and fair peer-review system, which is all easy to use. Visit http://www.dovepress.com/ testimonials.php to read real quotes from published authors. 